Article

\title{
Assessing the Social Sustainability Indicators in Vernacular Architecture-Application of a Green Building Assessment Approach
}

\author{
Obafemi A. P. Olukoya ${ }^{1, *}$ and Jubril O. Atanda ${ }^{2}$ (D) \\ 1 Department of Environmental Planning, Brandenburg Technical University, \\ 03046 Cottbus-Senftenberg, Germany \\ 2 Department of Architecture, Cyprus International University, Haspolat, Mersin 10, North Cyprus; \\ jubrilatanda@yahoo.com \\ * Correspondence: olukoyaobafemi@yahoo.com
}

Received: 23 July 2020; Accepted: 28 August 2020; Published: 1 September 2020

\begin{abstract}
Although a growing body of research has debated the array of sustainability lessons of vernacular architecture, social sustainability discussions remain less advanced in comparison to the other pillars of sustainability. This has narrowed the plural lessons of vernacular architecture and limited the broad concept of sustainability to a partial one. Against this research gap, this study aims to conduct an assessment of the social sustainability of residential vernacular architecture through the application of a proposed Social Criteria of Green Building Assessment Tool (SCGBAT) assessment method. The SCGBAT proposes eight sets of social criteria categories namely; health and safety; participation and control; education; equity, accessibility and satisfaction; social cohesion; cultural values; physical resilience and also, 37 indicators for the evaluation of social sustainability. To empirically operationalize the proposed SCGBAT, this study utilizes the vernacular architecture typologies in the vernacular landscape of Louroujina village in Cyprus as a case study. Methods for data collection are desk review for secondary data while 135 close-ended questionnaires were used for primary data. The data are statistically presented based on Linkert scale and interpreted using both quantitative and descriptive analysis. The results demonstrated that the investigated vernacular architecture ranked lowly in Physical Resilience Indicator (PRI), Environmental Education Indicator (EEI), Accessibility and Satisfaction Indicator (ASI) but demonstrated sufficient lessons in the context of Health and Safety Indicator (HSI); Participation and Control Indicator (PCI); Social Equity Indicator (SEI); Social Cohesion Indicator (SCI); and Cultural Value Indicator (CVI). To this end, this paper contribute to the advancement of knowledge on the assessment of the social sustainability of vernacular architecture by innovatively applying a green building assessment approach and identifying the strengths and weaknesses of such approach in a vernacular setting.
\end{abstract}

Keywords: vernacular architecture; social sustainability; social criteria of green building assessment tool (SCGBAT); Louroujina settlement

\section{Introduction}

Owing to the recent growing array of environmental challenges, researchers and practitioners began to suggest and debate the sustainable character of vernacular architecture in relation to contemporary buildings which in many cases, are associated with a range of environment depleting characterization such as carbon footprints, uncontrollable energy consumption, wasteful use of resources and pollution [1]. The ecological friendliness of vernacular architecture, its passive technologies and its rootedness with vernacular tradition continue to be positioned as a repository of knowledge and 
values which the contemporary construction industry can draw on for any attempt to develop more sustainable built environments. As such, vernacular architecture has gained a renewed interest and its imagery is no longer relegated to the nostalgic aide-mémoire of long-forgotten past or mere roadblocks to contemporary progress.

However, despite the renewed interest, all the representations of vernacular architecture lessons have operated under preconceived themes that privileges environmental sustainability over other pillars of sustainable development. Even while most of the researches has been accomplished through diverse disciplinary backgrounds, the devotion to the idea of assessing the extent to which vernacular materials perform in the context of environmental sustainability continues to unite most of the studies. Most of the studies investigate vernacular architecture in relation to its thermal properties in the way the material, layouts and building types relate to the microclimate and geographical conditions [2-5].

Given this reductionist representation of vernacular architecture in the broad literature, this paper argues that it has limited the broad concept of sustainability and narrowed the plural lessons of vernacular architecture is a partial one. Even while a large continuing body of scholar has demonstrated the importance of the social pillar of sustainability in sustainable development [6-9] and with vernacular architecture being conceptualized as the objectification of social relations [10], studies that treat this pillar in relation to lessons of sustainability in vernacular architecture remain less advanced. Given this identified research lacuna, this study aims to conduct the assessment of social sustainability indicators in vernacular architecture. To pursue this nature of research aim, green building assessment approach, among others, provides a platform for assessment of such sustainability indicators. Against this background, this paper adopts a proposed Social Criteria of Green Building Assessment Tool (SCGBAT) for the assessment of social sustainability in vernacular architecture. To empirically delineate the research aim, the study draws on a case study approach to operationalize the proposed SCGBAT.

To organize this paper and structure the argumentations, it is organized into two main parts. Part 1 is the theoretical review aspect which led to the adoption of the SCGBAT while part 2 is the application of the tools through a case study approach. Part one is organized into the following sections; following this introduction part is Section 2, which dwells on a rapid review of vernacular architecture and sustainability discourse. The following subsection focuses on the review of green building assessment tools in relation to social sustainability assessment. Also, the section explains the SCGBAT and the reason for the choice of selecting the tool for this research. Part 2 of this paper begins from Section 3, which is the methodology applied to organize and structure the operationalization of the SCGBAT. The section also gives the background to the case study and the building characterizations. Section 4 shows the results, Section 5 discusses the results and the implication of the data while Section 6 is the conclusion part of the paper. Based on this structuring of this paper, this study contributes the identified research gap by drawing on a green building assessment approach to demonstrate how to assess the social sustainability indicators in vernacular architecture.

\section{Vernacular Architecture and the Sustainability Discourse}

As an introduction caveat, this section does not attempt to provide a holistic review of the discourse of vernacular architecture and sustainability, as such would require a book-length treatment [11]. This section only aims to provide the important summations of the discourses as regards the pillars of sustainability with reference to vernacular architecture. By vernacular architecture, this paper refers to buildings that are regionally representative, regionally distinctive and regionally understood [12]. By extension, this definition includes the architecture of a precinct and/or a people or of an ethnic group, who lives in a particular geographical location [13]. Over the last 2 decades or so, this typology of architecture has emerged as a term that has taken up a life, not only within cultural heritage studies but also within the discourse of sustainability and sustainable development as well. For this reason, a large continuing body of works has demonstrated its values and why vernacular architecture should be taken seriously in architectural practice, for example, References $[1,14,15]$. The most frequent expression which summarizes the aims of the research includes, 'lessons from vernacular architecture' 
and 'learning from the vernacular' for example, References [16-29]. As such, it has simply become related to specific arguments such as positioning it as a didactic alternative to the contemporary architecture which is associated with uncontrollable greenhouse gas emission, disproportionate energy consumption and unsustainable use of earth's resources $[1,27,28]$. Thus, the recent discourses on vernacular architecture in relations to sustainability have been accomplished arguably under the following groups of studies.

First, there is a group of study that demonstrates the environmental sustainability lessons that can be drawn from vernacular architecture. In this context, it is explained that vernacular architecture holds enormous lessons as demonstrated by a growing body of researches which has illustrated it through various case studies $[25,27,28,30-37]$. Some studies also demonstrated through various computer-based modeling how vernacular architecture have a lower carbon footprint and consumes lesser energy in comparison to modern buildings in the regions, for example, References [27,28]. In the same vein, some of the studies also demonstrate how vernacular buildings are more thermally comfortable than the contemporary building by employing climatically responsive technologies, building techniques, materials and technologies without recourse to active mechanical means. For example, Praytino and Winaktoe [2] used an ecological model based approach on vernacular housing to demonstrate this relevance. Shaffer [5] also attempted to reinvent similar vernacular elements by synthesizing it using modern techniques. Dayaratne [3,4] equally demonstrated how traditional earth construction material and techniques were reinvented in Sri Lanka for sustainability and as common alternative to modern concrete technologies. Some of the studies also examined the techniques and technologies employed in vernacular settlements which make them responsive to the environment and therefore contribute to sustainability [38]. Lastly, there are also researches which demonstrate how vernacular architecture respond to geographical conditions geological and environmental resources and have fashioned the buildings that are sensitive to the prevailing environmental conditions [39-41].

The second group of studies emphasizes the economic sustainability lesson of vernacular architecture by suggesting that it responds and satisfies the needs of a community in the context of being more self-sufficient through sustaining the production and optimizing of local material by choosing to build through a collective communal effort [11]. In this regard, this group of studies suggested that vernacular architecture is more efficient management in the local resources which in turn becomes the main goal of any community $[11,42,43]$. Also, vernacular architecture has judicious use of resources which are scarce such as water or wood in arid environments [30,31,43]. This holds substantial lessons for the contemporary building industry on how to manage available resources for the sake of the future generation.

The third group of studies adumbrate the cultural sustainability lessons that can be drawn from vernacular architecture by suggesting that it encourages the re-establishment of the anthropological and social particularity of a specific locality [44,45]. It is often described as a non-arrogant, connected, peaceful, minimalist architecture that is in organic association with its site, topographies. It embodies intangible knowledge as well as tangible know-how and it is a testimony to the genial capacity of adaptation of the human to environmental constraints and opportunities. With this in view, vernacular architecture is argued to demonstrates cultural sustainability lesson through its approach which demonstrates the capacity to transform locally available materials (such as earth, stone, plants, wood) into construction elements and buildings (such as stables, houses, mosques and churches) that are organic with its place and addresses the social and the cultural identity of the particular locality [11]. Against this background, vernacular architecture is an incubator of regional identities, traditional craft and technique, human creativity and collective memory [46]. Summarily, according to these studies, the loss of vernacular architecture is tantamount to loss of traditional knowledge, regional and local identities. It also equals the loss of collective memory, loss of languages, traditional crafts and techniques and a continuum of lessons in the context of sustainable development as demonstrated by the overview in this section. 
As demonstrated by the rapid review, despite of the plethora of research position and the growing interest in the discourse of vernacular architecture, the social dimension which is equally an important component of vernacular settlement and their innate traditions, remains less advanced than researches in the direction of environmental sustainability. Thus, as a contribution to the existing scant positions in the context of social sustainability, this study adopts a building assessment system as an approach to assess the social dimension of vernacular buildings. However, before this is done, it is important to give a background to the building assessment tools and the understanding of social sustainability in the building assessment processes. In this regard, the following section gives an overview of the rating system and their approach to the assessment of social sustainability.

Building Assessment Tools, Social Sustainability and Proposed Social Criteria for Green Building Assessment (SCGBAT)

Over the years, Green Building Assessment Tools (GBATs) have grown to become the banner conveying the sustainability standards in different locations around the world. It has become widely adopted to reduce carbon emission, reduce energy consumption and providing the basis for healthy and comfortable building spaces while generating benefits for environmental, economic and social aspects [47]. Building assessment tools have been developed with a specific end goal to aid the application of sustainable development in the building and construction sector. It is a tool developed for the specific goal of ensuring sustainable development in the construction sector [48]. It is applied with the sole intent of evaluating, promoting and enhancing the comprehensive understanding of sustainability in the building industry through data evaluations, investigation and differentiation $[49,50]$. As such, different countries have developed different contextual building assessment tools such as the Building Research Establishment Environmental Assessment Method (BREEAM), Leadership in Energy and Environmental Design (LEED), Comprehensive Assessment System for Built Environment Efficiency (CASBEE) and the Deutsche Gesellschaft für Nachhaltiges Bauen (DGNB)—to mention a few-to ensure sustainable development in the different countries [48]. Two basic tools characterize the operationalization of the assessment of GBATs: the life cycle assessment tool and the criteria based tools. Enormous researches have been conducted in the direction of the criteria based assessment tools such as LEED, BREEAM, CASBEE and Green Star among others [51].

However, despite the robustness in the importance of GBATs, the social aspect remain less elaborate in comparison to the other pillars of sustainability. Despite the growing body of scholarly works have suggested that sustainable development requires the three pillars: environmental criteria, economic criteria and social criteria to acts as a continuum for sustainable development to be achieved [52-59]. Yet, appraisal of the criteria tools for the GBAT indicates that significant attention continues to be drawn to the environmental criteria of most building assessment tool while the social criteria remain in flux. This material essentialism of the most popular building tools reduces their effectiveness in the context of representing the social dynamics of a particular setting. More so, some of these tools are customer-needs oriented to such an extent that designers embark on pursuing credits [60].

In the literature, the importance of social sustainability has generated a plethora of positions over the years. For example, a study [61] explained social sustainability with regards to dual two factors, namely, equity and democracy. A study [6] also suggested that it as a movement that comes to play while regulating the progress of civil society, while the improvement brings about a rich environment. Meanwhile, Reference [7] explained it as a longtime association between society and nature. Furthermore, Reference [8] explained social sustainability to be contributory, enlightening and sustaining human welfare. Another study [9] argued that social sustainability is accomplishable if a project incorporates environmental understanding while lessening the social differences and hierarchies and in the same vein, enhancing personal satisfaction. These understandings of social sustainability have enormous utility with regards to the understanding of the conceptual dimension of vernacular architecture as an objectification of social relations [10]. As such, any assessment of sustainability in such buildings or of new development in such a context must incorporate the profound necessity 
for social sustainability. Thus, socially sustainable approaches in building assessment tools will be necessary to elucidate the relationship between the building and its users in an incorporated way, in this manner, factoring in both environmental and social aspects of sustainability. Nevertheless, the GBATs lacks an approach which sufficiently involves a comprehensive assessment of stakeholders [60,62].

Therefore, against the background of the identified gap of social sustainability in GBATs, a recent study by Atanda [63] developed sets of social categories/indicators by drawing on social sustainability literature and the criteria available in the existing green building assessment tools to develop categories and indicators. Eight set categories (health and safety; participation and control; education; equity, accessibility and satisfaction; social cohesion; cultural values and physical resilience) were suggested and tailored based on the adoption of LEED working sheet thereby creating a working sheet termed Social Criteria for Green Building Assessment (SCGBAT). The suggested 8 social categories are accompanied by 35 indicators that were selected by the application of a two-round questionnaire responded to by qualified experts for the support of evaluation for social criteria in GBAT. The categories and indicator as illustrated in Table 1 below.

Table 1. The final set of 8 social categories and 35 indicators for social sustainable developed [51,63].

\begin{tabular}{|c|c|c|}
\hline $\begin{array}{l}\text { Social Sustainability } \\
\text { Indicator Categories }\end{array}$ & Social Sustainability Indicator Sets & Individual Social Sustainability Indicators \\
\hline \multirow[t]{2}{*}{ Social equity } & Equity of process & $\begin{array}{l}\text { 1. Access to information } \\
\text { 2. Participation in decision making } \\
\text { 3. Formation of governance structure }\end{array}$ \\
\hline & Fair distribution & $\begin{array}{l}\text { 4. Planning of space } \\
\text { 5. Use of natural resources }\end{array}$ \\
\hline \multirow[t]{2}{*}{$\begin{array}{l}\text { Environmental } \\
\text { education }\end{array}$} & Environmental awareness \& sensibility & $\begin{array}{l}\text { 6. Material choices } \\
\text { 7. Energy sources } \\
\text { 8. Water and waste management } \\
\text { 9. Pollution } \\
\text { 10. Biodiversity }\end{array}$ \\
\hline & Ecological literacy & $\begin{array}{l}\text { 11. Awareness of the physical environment } \\
\text { 12. Knowledge of human activity on the environment } \\
\text { 13. Ability to take actions to environmental problems }\end{array}$ \\
\hline $\begin{array}{l}\text { Participation \& } \\
\quad \text { control }\end{array}$ & Involvement & $\begin{array}{l}\text { 14. User participation } \\
\text { 15. Willingness to act and improve environment } \\
\text { 16. Creative place making opportunities }\end{array}$ \\
\hline \multirow[b]{2}{*}{ Social Cohesion } & Social programs & $\begin{array}{l}\text { 17. Conferences \& seminars } \\
\text { 18. Neighborhood involvement in design and } \\
\text { planning phases }\end{array}$ \\
\hline & Social interaction & $\begin{array}{l}\text { 19. Design of a place which increases social } \\
\text { interaction within the building } \\
\text { 20. Design of a place which increases social } \\
\text { interaction with common spaces (fluid spaces) in the } \\
\text { neighborhood }\end{array}$ \\
\hline Health \&Safety & Health \& Safety measures & $\begin{array}{l}\text { 21. Health impacts of materials } \\
\text { 22. Health impacts of energy sources } \\
\text { 23. Health impact of water consumption } \\
\text { 24. Health impacts of IEQ } \\
\text { 25. Feeling of safety }\end{array}$ \\
\hline \multirow[t]{2}{*}{$\begin{array}{l}\text { Accessibility \& } \\
\text { satisfaction }\end{array}$} & Ease of accessibility & $\begin{array}{l}\text { 26. Access to social information about green building } \\
\text { 27. Access to choice of natural resource } \\
\text { 28. Project location for public access }\end{array}$ \\
\hline & Satisfaction level & 29. Post-Occupancy Evaluation \\
\hline Cultural value & Local identity & $\begin{array}{l}\text { 30. Design of spaces } \\
\text { 31. Indigenous environmental management practices } \\
\text { 32. Intercultural dialogue }\end{array}$ \\
\hline Physical resilience & Disaster resilience and mitigation & $\begin{array}{l}\text { 33. Compliance to earthquake resistance code } \\
\text { 34. Mitigation in the use of environmental resources } \\
\text { 35. Sustainable management of hazards }\end{array}$ \\
\hline
\end{tabular}

To operationalize the suggested categories and indicators, the author applied Analytic Hierarchy Process (AHP) to find the most relevant measurement and weight for the resulting indicators and categories [see 61]. In this paper, social criteria are defined as an aspect that affects the final users within 
the living space of the building (indoors and outdoors) such as its health, safety, visuals, accessibility, cultural values and participation in attaining sustainability. According to this understanding of social criteria and based on the adopted definition, the approach, indicators and categories suggested and integrated by Reference [63] is considered to be appropriate to achieve the research aim of this study. In a vernacular settlement, people are often collectively involved in the creation, decision making and planning of vernacular spaces and as such affected by it. In this regard, any assessment in such contextual settlement must be people-driven. Thus, there is an imperative need for integrating social sustainability criteria into the building assessment tool for effective assessment in the case of vernacular settlement which is built contingent on the abundance of socio-cultural traditions in a particular setting.

\section{Methodology}

The data which leads to the argumentation in this paper is divided into primary and secondary data, respectively $[64,65]$. The secondary data draws on literature review to frame the secondary aspect of the research. The primary data draws on a case study approach to draw its empirical data as shown in Figure 1. Thus, the methodology is organized into four steps. The first step is concerned with the conceptual development which draws on the adoption of the Social Sustainability Green Assessment Tool (SGBAT) as developed by Reference [63] and References [44,51] as the guide for field inquiry and application of data collection methods. The second step is concerned with the case study and building identification. The justification for the selected buildings is explained through the developed criteria for selection. Step three is the identification of suitable primary data collection methods to be applied for data collection. In this case, a closed- ended questionnaire method is applied. Having considered the appropriate data collection methods, the implementation approach for the SCGBAT is done through fieldwork. The last step is the data analysis approach which leads to the discussion and the conclusion.

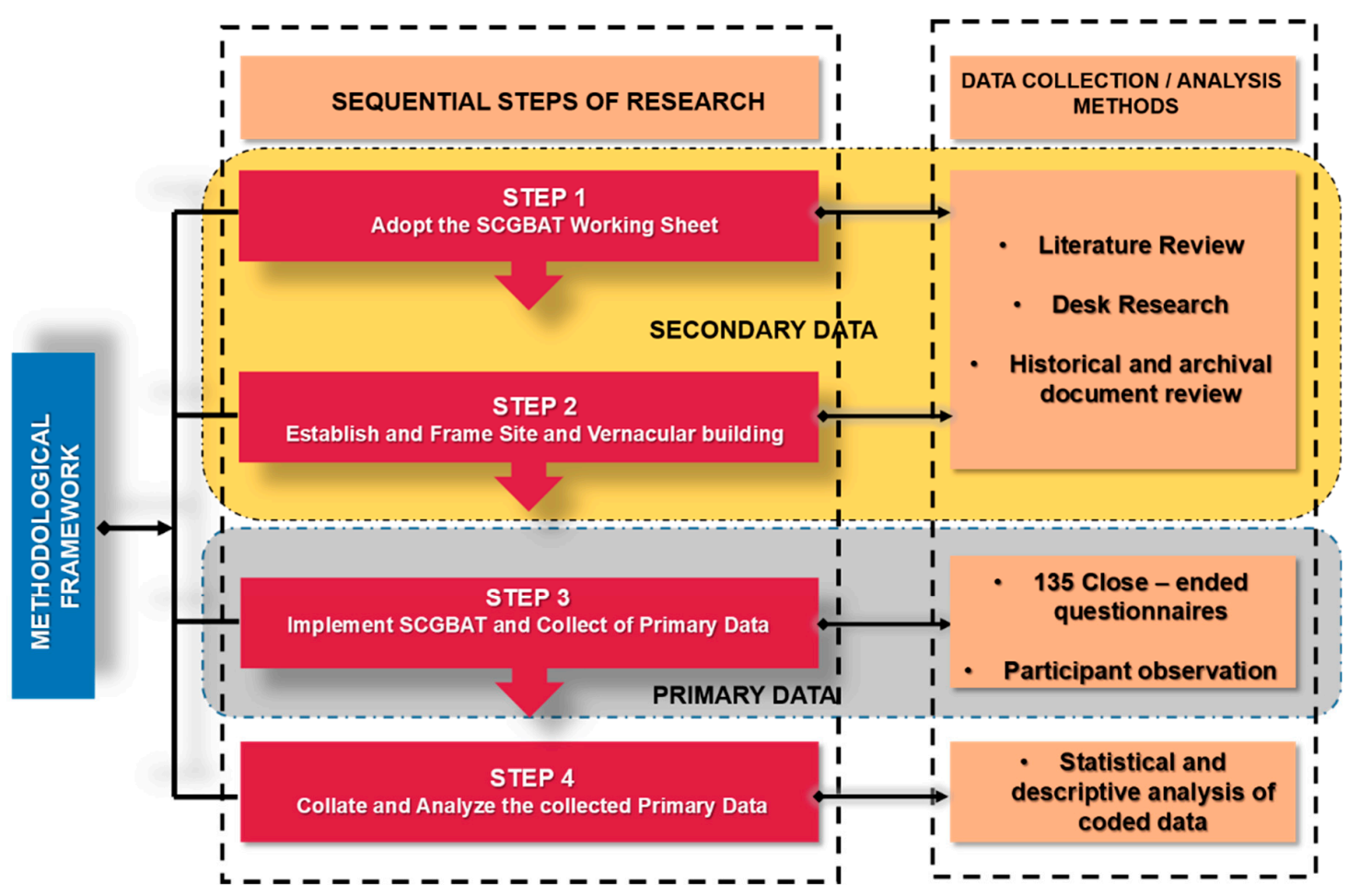

Figure 1. The methodological framework for research.

\subsection{Step 1: Adoption of Social Criteria for Green Building Assessment Tool (SCGBAT) Working Sheet}

The categories and indicators were assigned weightings by Reference [63], through the applications of Analytic Hierarchy Process (AHP) to find the most relevant measurement and weight for the resulting 
indicators and categories [see Reference 63].The weight point of each indicator is measured using the final weight score as seen in Table 2 below.

Table 2. Weighting score of the social categories and indicators [63].

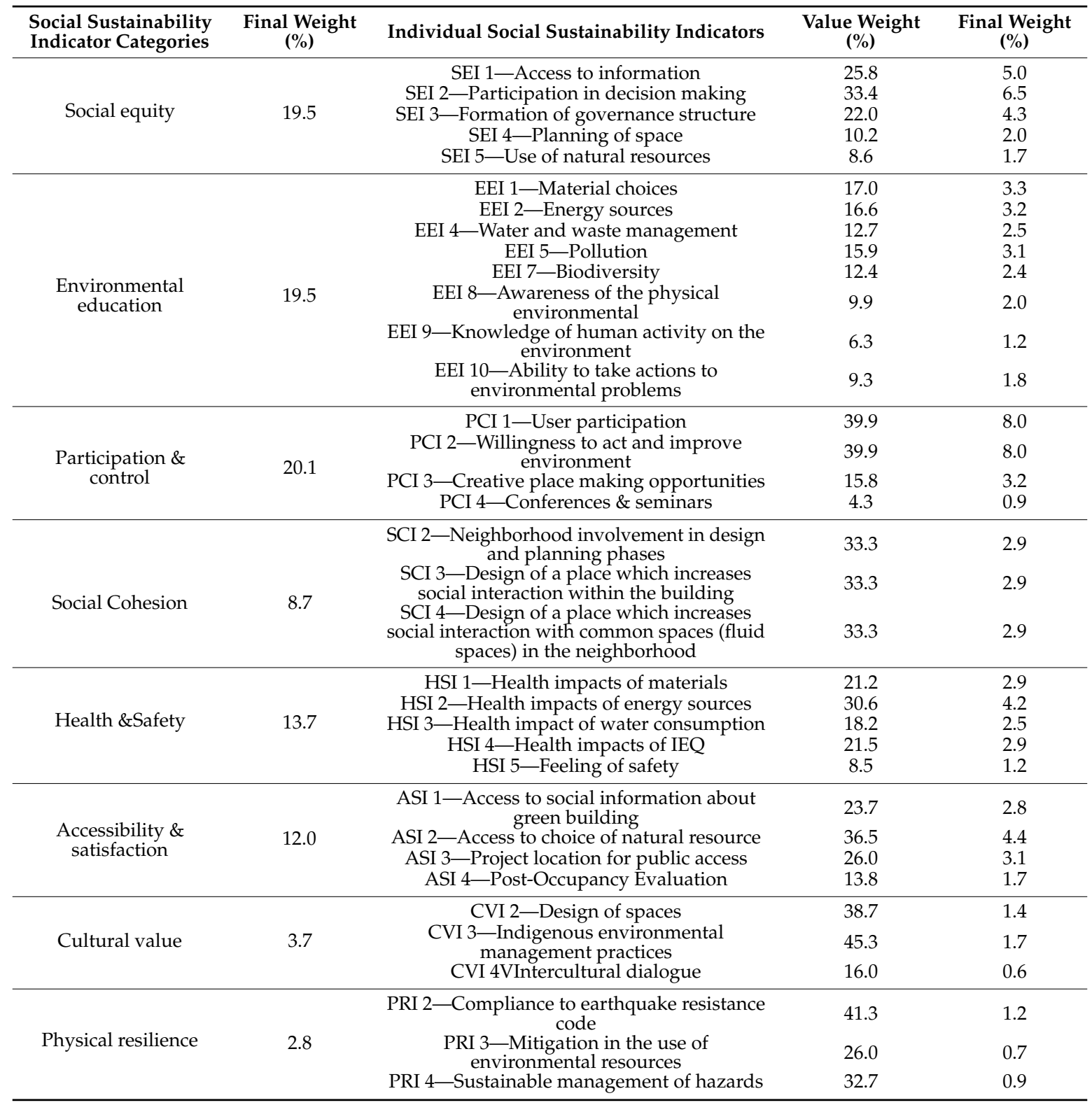

\subsection{Step 2: Case Study and Vernacular Building Identification for Implementation of SCGBAT}

Having adopted the SCGBAT framework, an initial selection of the site was done through a set of criteria which draws fundamentally on the theoretical conception of vernacular architecture and settlement. The understanding of vernacular architecture in this research draws on the definition of vernacular architecture according to a study [12] which defined it as buildings that are regionally representative, regionally distinctive and regionally understood. By extension, this definition includes the architecture of a precinct and/or a people or of an ethnic group, who lives in a particular geographical location [13] (p. 4). This 'contextualized' architecture as rightly described by a study [11], belongs to a particular geographical area, regional or to a 'country' and built in a given time. Vernacular architecture emerges from the 'genius loci' which is the 'being to the place' and of the sense of 'being of the place' [66]. Reference [67] (p. 132) defined regionalism as an umbrella term for vernacular architecture 
which he defined as a "communal art, not produced by a few intellectuals or specialist but by the spontaneous and continuing activity of a whole people with a common heritage, acting under a community experience." In all of these definitions, there is an important emphasis on the importance of the social dimension of vernacular architecture. Thus by drawing on these definitions stated above, Table 3 was developed to demonstrates the dimension for identifying what constitutes vernacular architecture according to the following analytical themes, (1) conceptual reference; (2) authorship; (3) planning process; (4) production process; (5) user; and, (6) the language of heritage [68].

Table 3. The Simple dimension of what constitutes vernacular architecture, adapted based on [68].

\begin{tabular}{cc}
\hline Criteria & Vernacular Expression \\
\hline Conceptual reference & Non Academic/Informal \\
\hline Author & Non Specialist/anonymous in some cases \\
\hline Planning process & Collective/communal/intuitive/mental/schematic \\
\hline Production process & Artisanal and constructed/Commonly use locally available material \\
\hline User & $\begin{array}{c}\text { In general refers to the visual culture of the suburbs and from the classes with lower } \\
\text { purchasing power. Reveals the working tools and the raw materials used by the } \\
\text { artisans. Utilizes chromatic and pictorial codes familiar to the popular universe } \\
\text { Language of heritage }\end{array}$ \\
\hline
\end{tabular}

Against the background of this definition and criteria, Louroujina village in Cyprus was considered to satisfy almost all of the defining criteria for what constitutes vernacular settlement and its architecture. Having identified the settlement and buildings, the next step is to define the objectives. The objectives were designed in a hierarchical manner such that it reflects the target goals for which the performance of SCGBAT indicators would be based. The building function is also clearly defined. This is to assist the measurement of the indicators. As shown in Figure 2 below, the target value of the building project is also clearly stated, for example, for children, elderly people, students, staff or general public and so forth, is clarified.

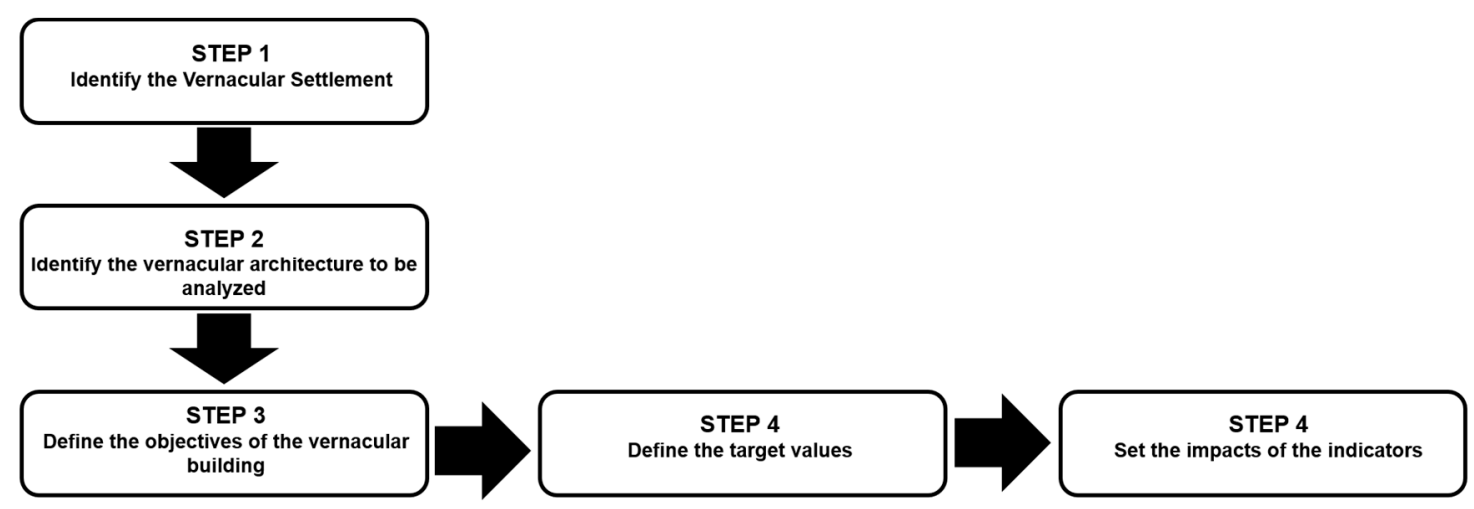

Figure 2. Sequence for identifying the objectives, target values and the impact of the indicators.

Having framed the site and the vernacular buildings, the implementation of the "SCGBAT" indicators begins. Each of the indicators is used to measure and monitor the objectives of the vernacular building as shown in the steps illustrated in Figure 2.

\subsubsection{Introduction to Case Study: Louroujina Vernacular Settlement, Cyprus}

Cyprus is the third largest island in the Mediterranean Sea after Sicily and Sardinia. It is geographically located on the $35 \mathrm{~N}$ meridian. Historically, Cyprus became known around 10,000 BC. 
Cyprus became divided into the North part \& South part in 1974, North Cyprus area is around $3355 \mathrm{Km}^{2}$ [69] (see Figure 3).

Louroujina village which is the case study of this research is situated in the Northern part of Cyprus. Geographically, the village is located at longitude $350^{\circ} 00^{\prime} 42^{\prime \prime}$ North and latitude $330^{\circ} 27^{\prime} 51^{\prime \prime}$ East with altitude of $236 \mathrm{~m}$ [70]. Although the precise origin of Louroujina remains far from clear, one thing is certain, however, as a member of the over 650 towns and villages on the Island, the history dates back to possibly the 12-13 century AD [71]. In 1958, Turkish Cypriots adopted Akıncilar as its alternative name. Akıncllar literally means "Ottoman raiders" in Turkish [72]. What is simply unique about Louroujina village is that, till date, only a very few modern building exists in the village and vernacular building culture remains intact.

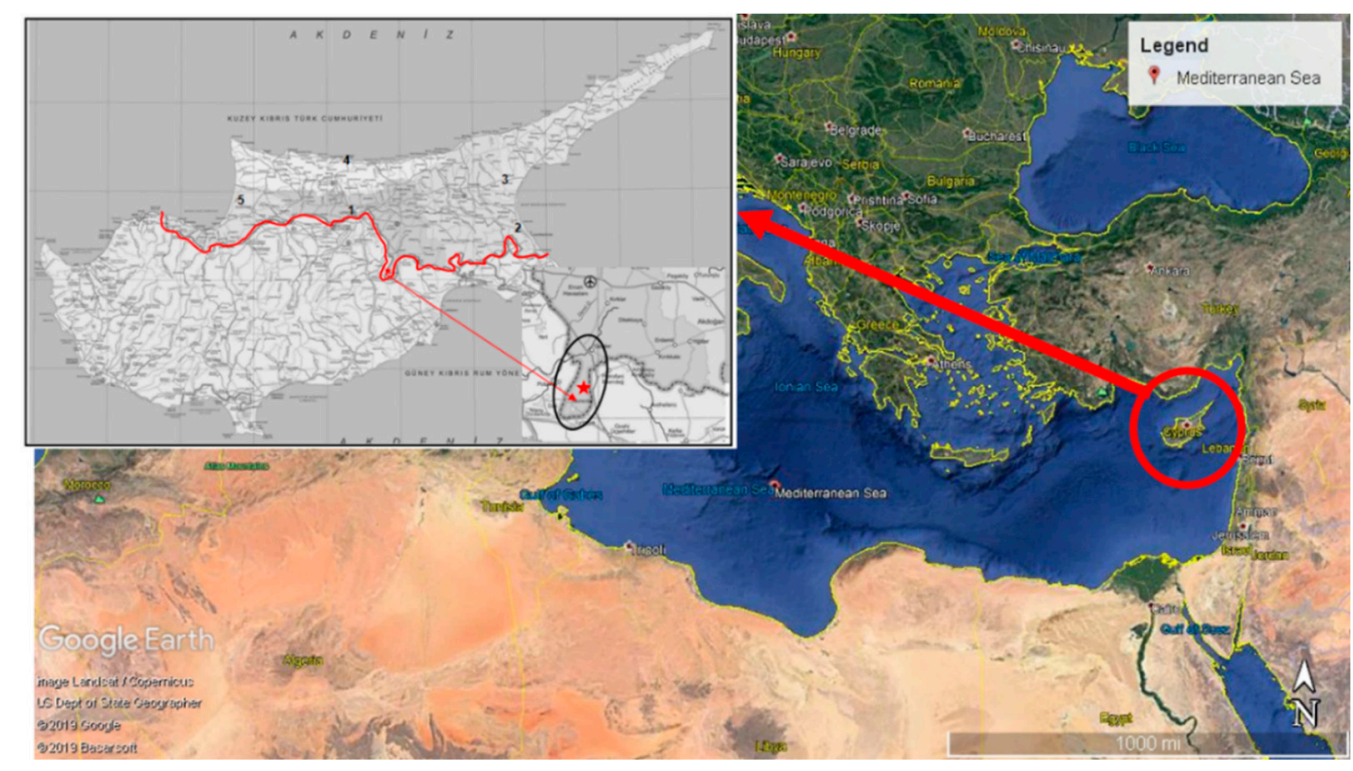

Figure 3. The Location of Louroujina Village in Cyprus [73].

\subsubsection{Typologies of Vernacular Architecture in Louroujina}

According to the recently concluded research project conducted in Louroujina, there are four typologies of vernacular houses in the village [72]. Typology in this context refers to a group of building which shares the same plan configuration and façade characteristics. In this regard, the typologies of vernacular architecture in Louroujina are a function of the combination of two parameters, namely; the plan characteristic and façade characteristics. Table 4 below illustrates the typologies of plans evident in Louroujina today. 
Table 4. The typologies and characteristics of vernacular architecture in Louroujina.

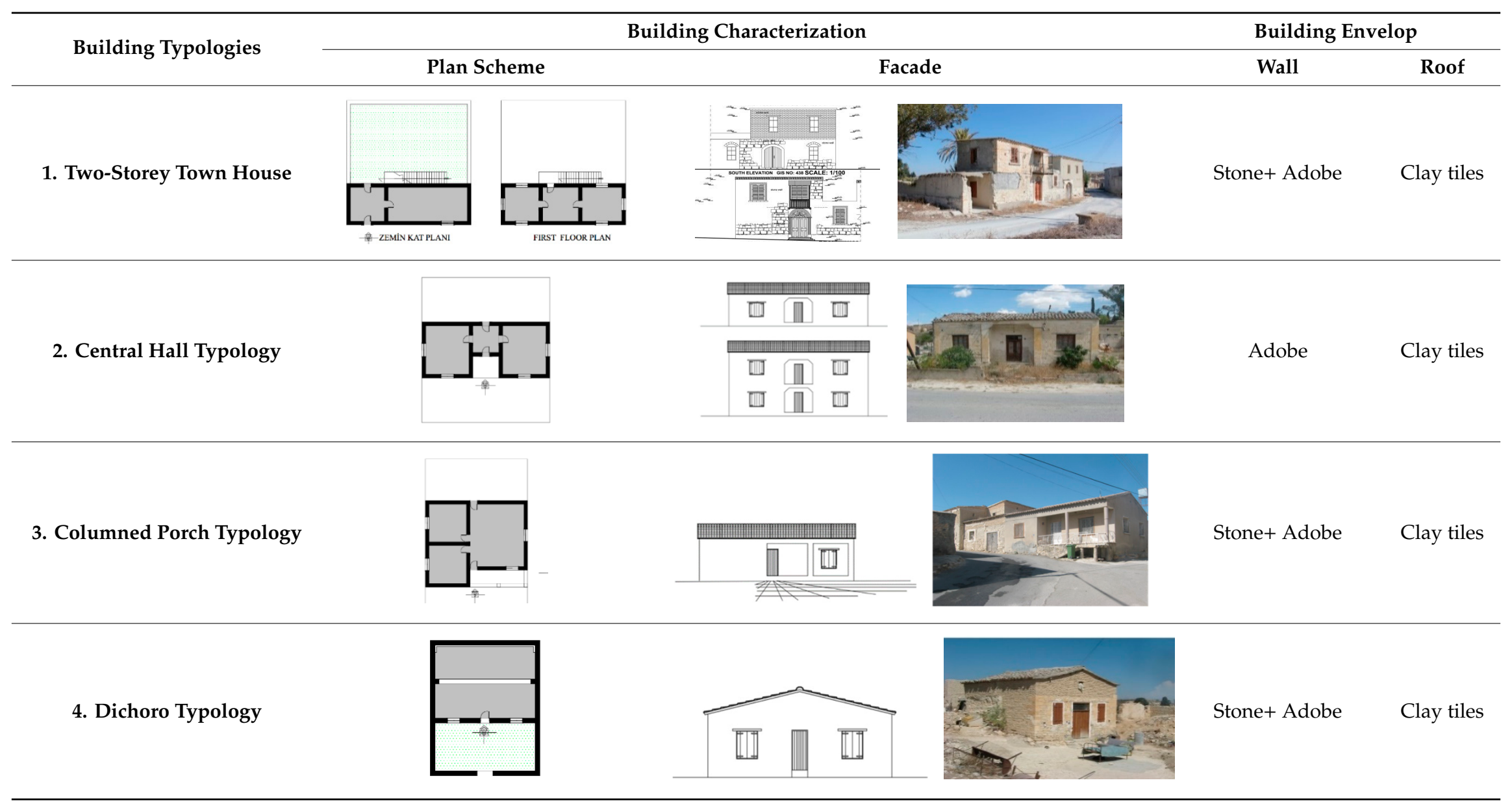




\subsection{Step 3: Data Collection Approach}

\subsubsection{Closed-Ended Questionnaire}

A closed-ended questionnaire approach was applied to gather data from selected participants. The questionnaire consisted of structured questions with each addressing questions concerning the specific categories and its indicators. A total number of 135 questionnaires were distributed between December 2019 and February 2020. Each of the 8 social categories was assigned different questions based on the objective of the data to be collected. There was a flexible time frame for the questionnaires so that the respondents are more flexible and provide greater clarity in their answers. In some cases, follow-up questions were applied to ensure consistency and reevaluate the responses. In some cases, a translator was used to communicate with the respondents, especially in Turkish language.

\subsubsection{Selection of Participants}

The choice of participants was selected with snowball method, availability of respondents and the determined number of questionnaires. The question sub-categories are stratified with regards to the affiliation to Louroujina village, roles, gender, experience and level of education of participants in certain cases. A total number of 135 respondents were used for the research. 121 of the respondents are community members and occupants of the vernacular building typologies. The number amounted to $35 \%$ of the population of the village. The other 14 respondents are professionals and experts working on the funded restoration project in the village (see Table 5). The participant comprises of both males (83) and females (52), allowing mixed-gender perspectives and encouraging the diversity of opinion in the discussion. The names of the respondents remain anonymous throughout the paper. The analysis of the data was based on a descriptive data analysis approach given the qualitative nature of the data.

Table 5. The characteristics of the participants used for the questionnaire procedure.

\begin{tabular}{ccc}
\hline Participant Group & Affiliations & $\begin{array}{c}\text { Number of } \\
\text { Participant }\end{array}$ \\
\hline Professionals and Experts & $\begin{array}{c}\text { Cyprus International University } \\
\text { Heritage } \begin{array}{c}\text { Site Managers at the Department of Antiquity } \\
\text { Louroujina Municipality office }\end{array}\end{array}$ & 14 \\
$\begin{array}{c}\text { Community Members, house } \\
\text { owners and Stakeholders }\end{array}$ & House owners & 121 \\
& $\begin{array}{c}\text { Organized groups and NGOs } \\
\text { Owners in Diaspora } \\
\text { Occupant and households }\end{array}$ & \\
\hline
\end{tabular}

\subsection{Step 4: Evaluation and Data Analysis}

The questions are simple and direct, which were validated by References [73-76]. In this regard, the questions were analyzed based on the validity of the Likert scale. The respondents were asked to assess the indicators in five-point Likert scale. The 5 point scale was selected to minimize skewed responses. The responses were scored according to 1, 2, 3, 4 and 5 respectively. Because the assessment was based on five-point Likert scales, a score of 5 is analyzed as the highest and 1 is the lowest agreement with the questions from the respondents' perception. The respondent was expected to select their choice by marking a number along with the scale. If the respondent considered that factor was not relevant to the selection of the SCGBAT, they were requested to make suggestions. For the first round of questionnaires distributed to the 121 residents in/or connected to Louroujina village and 117 was returned. The first round of questions was used to understand the local perspectives of the SCGBAT indicators adopted. The first round of questionnaires stated the purpose of the study. Locals were asked to rate the relevance of the indicators using a five-point Likert scale. It aimed at exploring the terminologies of the indicators to the local and familiarizing them with the study. After the analysis of the first round, the response from the locals was evaluated by SPSS software to calculate the mean and 
standard deviation. In the analysis the result a parametrical statistical analysis was adopted where the mean was used to measure the control of tendency and the standard deviation to measure the degree of convergence [77,78].

To conduct the second round, the number of participants of experts had to be determined. The literature agrees that there is no standard range of sample size [79]. For a homogeneous study, smaller sample size is preferable and might yield sufficient results and for a heterogeneous study, a larger sample size might be suitable [80]. Taylor-Powell [81] stated the number of experts depends solely on the research objective. However reaching on a determination that somewhere in the range of 30 and 50 participants are sufficient to establish the purposeful on the research and the variety of opinions [82] and due to the complexity of the study, a 30 member expert was decided. The second round of questionnaire which was distributed to the experts both in the academia and the industry via an online link, all the 14 was returned which signified $90 \%$ total response rate.

While conducting the second round, the result accumulated from the first round was measured by the experts. The experts were then asked to rank the indicators in a review of the response from the first round. After the finish of the second round, the mean score and standard deviation of the indicators were again ascertained to gauge the level of convergence. The responses from the second round were used as the benchmark of the analysis.

The result generated from the expert was analyzed using SPSS to calculate the mean, the mean was converted into a percentile value (see Table 6). To derive the total value of the respondents (experts) using Table 6 below to demonstrate the percentile rate from the Likert scale. Each question was rated as $100 \%$, based on the adopted SCGBAT model (Table 6), each individual indicator has its weight value.

Table 6. Likert scale, the points and the values.

\begin{tabular}{ccc}
\hline Likert Scale & Points & Values \\
\hline Strongly Agree & 5 & $76-100 \%$ \\
Agree & 4 & $51-75 \%$ \\
Neither Agree Nor Disagree & 3 & $26-50 \%$ \\
Disagree & 2 & $01-25 \%$ \\
Strongly Disagree & 1 & Nil \\
\hline
\end{tabular}

From the 14 returned answers the rating was derived through means as a benchmark for each indicator and it was calculated using the percentage of the total. As an example, SE1 3 the mean was calculated as $50 \%$ from the experts rating. Since the overall rating is 4.3 which is equal to $100 \%$, to get the actual point, after cross multiplication $x=2$, which is the value used in the RAG rating. See calculation below

$$
\begin{aligned}
4.3 & =100 \% \\
x & =50 \%
\end{aligned}
$$

Therefore $\mathrm{x}=2$.

This calculation is used for all the indicators to derive their final weights in the rating system.

Concerning the organization of the data, it followed the process of coding; all correlation and discrepancy are organized, coded and tabulated. Also, organizing of the data was achieved by interpretive coding through the tables produces and classification of the valid data to generate interpretations and verdicts from the collected data. In this regard, to assess the "SCGBAT" indicators, a RAG rating system (red, yellow and green) was adopted to provide a graphical representation of the results for the indicators and categories. The RAG rating system was developed to enable a proper presentation of the indicators analyzed. The RAG rating system is demonstrated as follows-green indicates a positive result with a high number (4-5), yellow indicates an average level of satisfaction (3), while red indicates a negative result ( 2 and 1 ). Figure 4 shows an example of the RAG rating system. 


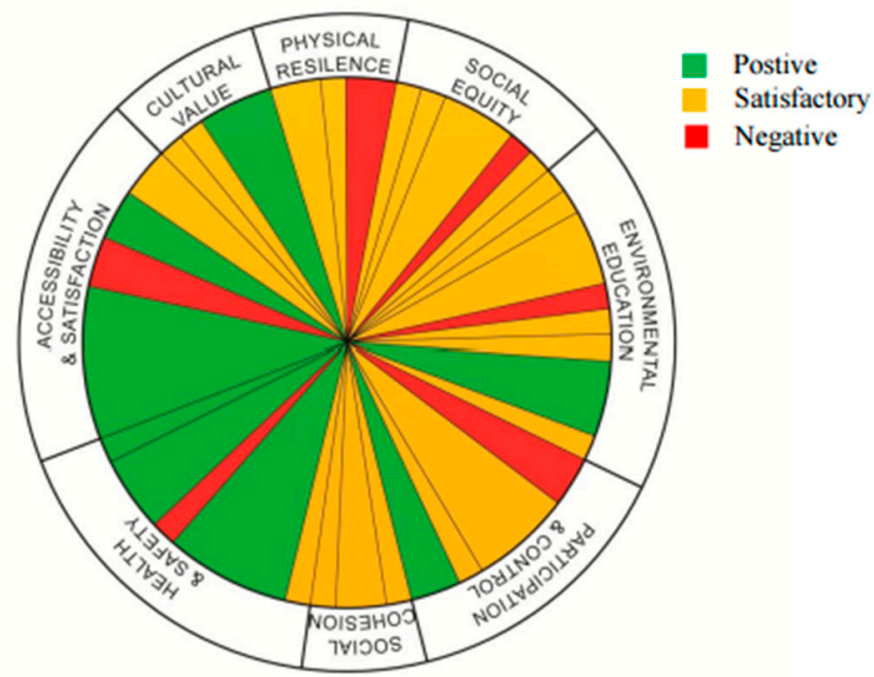

Figure 4. Sequence for identifying the objectives, target values and the impact of the indicators.

The Figure 4 above gives an overall presentation of the indicators from the SCGBAT indicators adopted. Each section of color represents the 36 indicators derived from the experts' response to the questions are evaluation. It shows the different levels of rating in each indicator with some indicators have a mix of higher individual indicators points than the others. This shows that a single indicator can have a positive response in all its indicators while some can have a variance of negative, average and positive ratings.

\section{Results}

The following Table 7 is the final result of the questionnaire, based on the SCGBAT working sheet.

Table 7. Results which led to the analysis.

\begin{tabular}{|c|c|c|c|c|}
\hline $\begin{array}{l}\text { Social Sustainability } \\
\text { Indicator Categories }\end{array}$ & Individual Social Sustainability Indicators & $\underset{(\%)}{\text { Final Weight }}$ & Results & $\begin{array}{c}\text { Percentile Value } \\
(\%)\end{array}$ \\
\hline \multirow{5}{*}{ Social equity } & SEI $1-$ Access to information & 5.0 & 5 & 100 \\
\hline & SEI 2-Participation in decision making & 6.5 & 5 & 75 \\
\hline & SEI 3-Formation of governance structure & 4.3 & 2 & 50 \\
\hline & SEI 4-Planning of space & 2.0 & 2 & 100 \\
\hline & SEI 5-Use of natural resources & 1.7 & 1.7 & 100 \\
\hline \multirow{8}{*}{$\begin{array}{l}\text { Environmental } \\
\text { education }\end{array}$} & EEI 1-Material choices & 3.3 & 3.3 & 100 \\
\hline & EEI 2-Energy sources & 3.2 & 1 & 25 \\
\hline & EEI 4-Water and waste management & 2.5 & 1 & 50 \\
\hline & EEI 5-Pollution & 3.1 & 3.1 & 100 \\
\hline & EEI 7-Biodiversity & 2.4 & 2 & 75 \\
\hline & $\begin{array}{c}\text { EEI 8-Awareness of the physical } \\
\text { environmental }\end{array}$ & 2.0 & 2 & 100 \\
\hline & $\begin{array}{c}\text { EEI 9-Knowledge of human activity on the } \\
\text { environment }\end{array}$ & 1.2 & 1.2 & 100 \\
\hline & $\begin{array}{c}\text { EEI 10-Ability to take actions to } \\
\text { environmental problems }\end{array}$ & 1.8 & 1 & 100 \\
\hline \multirow{4}{*}{$\begin{array}{l}\text { Participation \& } \\
\text { control }\end{array}$} & PCI 1-User participation & 8.0 & 8 & 100 \\
\hline & $\begin{array}{c}\text { PCI 2-Willingness to act and improve } \\
\text { environment }\end{array}$ & 8.0 & 4 & 50 \\
\hline & PCI 3-Creative place making opportunities & 3.2 & 3.2 & 100 \\
\hline & PCI 4 -Conferences \& seminars & 0.9 & 0 & 25 \\
\hline \multirow{3}{*}{ Social Cohesion } & $\begin{array}{c}\text { SCI 2-Neighborhood involvement in design } \\
\text { and planning phases }\end{array}$ & 2.9 & 2.9 & 100 \\
\hline & $\begin{array}{l}\text { SCI 3-Design of a place which increases social } \\
\text { interaction within the building }\end{array}$ & 2.9 & 2.9 & 100 \\
\hline & $\begin{array}{c}\text { SCI 4-Design of a place which increases social } \\
\text { interaction with common spaces (fluid spaces) } \\
\text { in the neighborhood }\end{array}$ & 2.9 & 2.9 & 100 \\
\hline
\end{tabular}


Table 7. Cont.

\begin{tabular}{|c|c|c|c|c|}
\hline $\begin{array}{l}\text { Social Sustainability } \\
\text { Indicator Categories }\end{array}$ & Individual Social Sustainability Indicators & $\underset{(\%)}{\text { Final Weight }}$ & Results & $\begin{array}{c}\text { Percentile Value } \\
(\%)\end{array}$ \\
\hline \multirow{5}{*}{ Health \&Safety } & HSI 1-Health impacts of materials & 2.9 & 2 & 75 \\
\hline & HSI 2-Health impacts of energy sources & 4.2 & 4 & 100 \\
\hline & HSI 3-Health impact of water consumption & 2.5 & 2 & 100 \\
\hline & HSI 4-Health impacts of IEQ & 2.9 & 2 & 75 \\
\hline & HSI $5-$ Feeling of safety & 1.2 & 1.2 & 100 \\
\hline \multirow{4}{*}{$\begin{array}{l}\text { Accessibility \& } \\
\text { satisfaction }\end{array}$} & $\begin{array}{l}\text { ASI 1-Access to social information about } \\
\text { green building }\end{array}$ & 2.8 & 0 & 0 \\
\hline & ASI 2-Access to choice of natural resource & 4.4 & 4.4 & 100 \\
\hline & ASI 3-Project location for public access & 3.1 & 3 & 100 \\
\hline & ASI 4-Post-Occupancy Evaluation & 1.7 & 0 & 0 \\
\hline \multirow{3}{*}{ Cultural value } & CVI 2-Design of spaces & 1.4 & 1 & 75 \\
\hline & $\begin{array}{l}\text { CVI 3-Indigenous environmental } \\
\text { management practices }\end{array}$ & 1.7 & 1.7 & 100 \\
\hline & CVI 4-Intercultural dialogue & 0.6 & 0.6 & 100 \\
\hline \multirow{3}{*}{ Physical resilience } & $\begin{array}{l}\text { PRI 2-Compliance to earthquake resistance } \\
\text { code }\end{array}$ & 1.2 & 0 & 0 \\
\hline & $\begin{array}{l}\text { PRI 3-Mitigation in the use of environmental } \\
\text { resources }\end{array}$ & 0.7 & 0 & 0 \\
\hline & PRI 4-Sustainable management of hazards & 0.9 & 0.2 & 0 \\
\hline
\end{tabular}

\subsection{Category 1: Social Equity Indicator (SEI)}

According to the responses gathered for category one of the social equity category, the majority of the indicators assessments were of positive ratings (see Table 8). However, concerning the formation of a governance structure indicator, it was gathered that policies based on environmental gain and loss were unequally implemented among the participants.

Table 8. RAG rating of Social Equity Indicator in Louroujina.

\begin{tabular}{|c|c|c|}
\hline Category Indicators & Indicators & Score \\
\hline & SEI 1-Access to information & $5 / 5$ \\
\hline SE ज SEI & SEI 2-Participation in decision making & $5 / 6.5$ \\
\hline & SEI 3-Formation of governance structure & $2 / 4.3$ \\
\hline$\frac{N}{\bar{u}}$ & SEI 4-Planning of space & $2 / 2$ \\
\hline & SEI 5-Use of natural resources & $1.7 / 1.7$ \\
\hline SOCIAL EQUITY & Total & 15.7 \\
\hline
\end{tabular}

\subsection{Category 2: Environmental Education Indicator (EEI)}

Environmental education category for Louroujina shows that majority of the indicator yielded a positive result (see Table 9), in particular, the awareness of the material choice used within the area, awareness of the physical environment and also the ability to take action towards any environmental problem facing them. However, the unsatisfactory score came from the energy sources, where users are not well learned about the energy input into their buildings and also an average understanding of the water and waste management was visible in the result (Table 9). 
Table 9. RAG rating of Environmental Education Indicator in Louroujina.

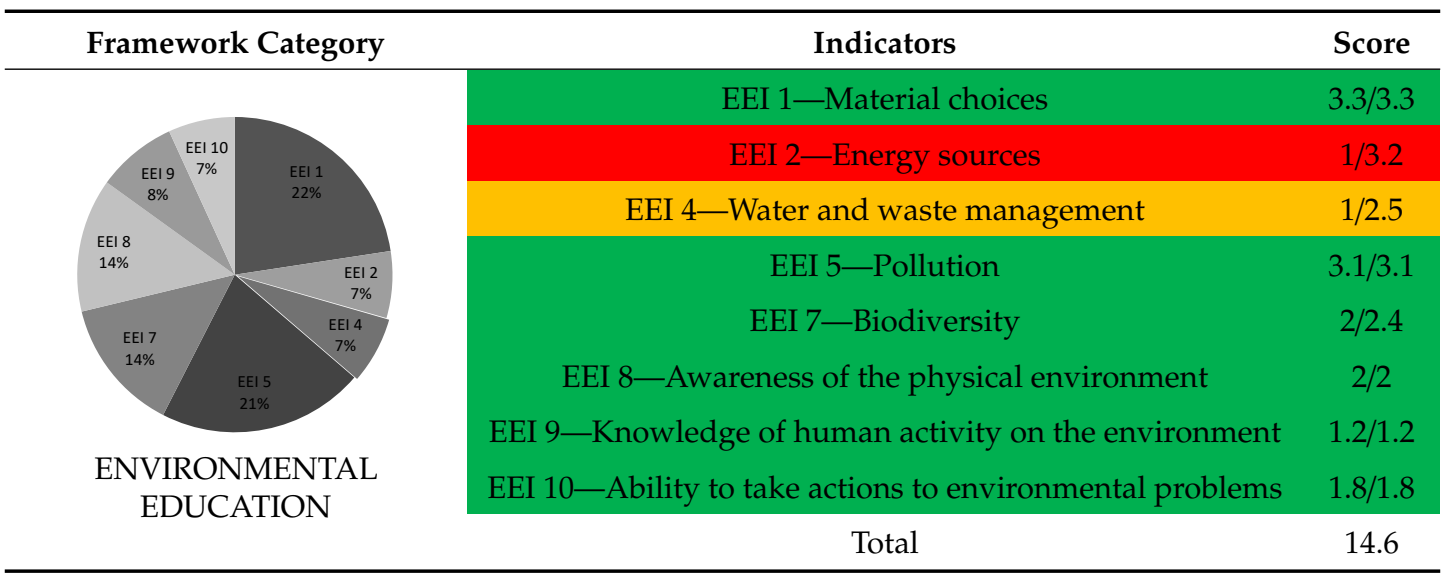

\subsection{Category 3: Participation and Control Indicator (PCI)}

The participation and control category shows an average rating between the indicators, with positive outcomes from the user's participation, where the users are highly involved in discussing environmental problems, ways of tackling them and their benefits to their community (see Table 10). However, the willingness to act toward improving the environment is on an average score. Whereas the lack of a congregational assembly (conferences or seminars) to discuss these problems are visible in the community (Table 10).

Table 10. RAG rating of Participation \& Control Indicator in Louroujina.

\begin{tabular}{|c|c|c|}
\hline Framework Category & Indicators & Score \\
\hline \multirow[t]{4}{*}{$\begin{array}{l}\mathrm{PC} 14 \\
0 \%\end{array}$} & PCI 1-User participation & $8 / 8$ \\
\hline & PCI 2-Willingness to act and improve environment & $4 / 8$ \\
\hline & PCI 3-Creative place making opportunities & $3.2 / 3.2$ \\
\hline & PCI 4-Conference and seminars & $0 / 0.9$ \\
\hline $\begin{array}{l}\text { PARTICIPATION \& } \\
\text { CONTROL }\end{array}$ & Total & 15.2 \\
\hline
\end{tabular}

\subsection{Category 4: Social Cohesion Indicator (SCI)}

Social Cohesion category for Louroujina shows that indicators were of positive ratings. The neighbors were involved in the planning and design phases, the design of the spaces helped boost their social networks both within the building and in common spaces (Table 11).

Table 11. RAG rating of Social Cohesion Indicator in Louroujina.

\begin{tabular}{|c|c|c|}
\hline Framework Category & Indicators & Score \\
\hline & SCI 2-Neighborhood involvement in design and planning phases & $2.9 / 2.9$ \\
\hline & $\begin{array}{l}\text { SCI 3-Design of a place which increases social interaction within } \\
\text { the building }\end{array}$ & $2.9 / 2.9$ \\
\hline sCl 3 & $\begin{array}{l}\text { SCI 4-Design of a place which increases social interaction with } \\
\text { common spaces (fluid spaces) in the neighborhood }\end{array}$ & $2.9 / 2.9$ \\
\hline SOCIAL COHESION & Total & 8.7 \\
\hline
\end{tabular}




\subsection{Category 5: Health and Safety Indicator (HSI)}

The health and safety category in Louroujina shows a positive result from the indicator assessment. All the indicators yielded a positive response based on the health impacts of material; energy sources; water; IEQ and safety measures. The occupants are well informed of the basic health issues relating to the subjects mentioned earlier (see Table 12).

Table 12. RAG rating of Health and Safety Indicator in Louroujina.

\begin{tabular}{lcc}
\hline Framework Category & Indicators & Score \\
\hline & HSI 1-Health impact of materials & $2 / 2.9$ \\
\hline HSI 2-Health impacts of energy sources & $4 / 4.2$ \\
HSI 3-Health impacts of water consumption & $2 / 2.5$ \\
HSI 3 HSI 4-Health impact of IEQ & $2 / 2.9$ \\
HEALTH \& SAFETY & HIS 5-Feeling of safety & $1.2 / 1.2$ \\
\hline
\end{tabular}

\subsection{Category 6: Accessibility and Satisfaction Indicator (ASI)}

Accessibility and Satisfaction category in Louroujina shows the mixed reaction of the indicators, where access to social information about green building within the community is at the least scores, this shows the level of information readily available to occupants to be very low, with no library or adequate knowledge of green building. Also, post-occupancy evaluation is not readily implemented in the community. However, access to natural resources and project location for the public is of higher impact in the community (Table 13).

Table 13. RAG rating of Accessibility and Satisfaction Indicator in Louroujina.

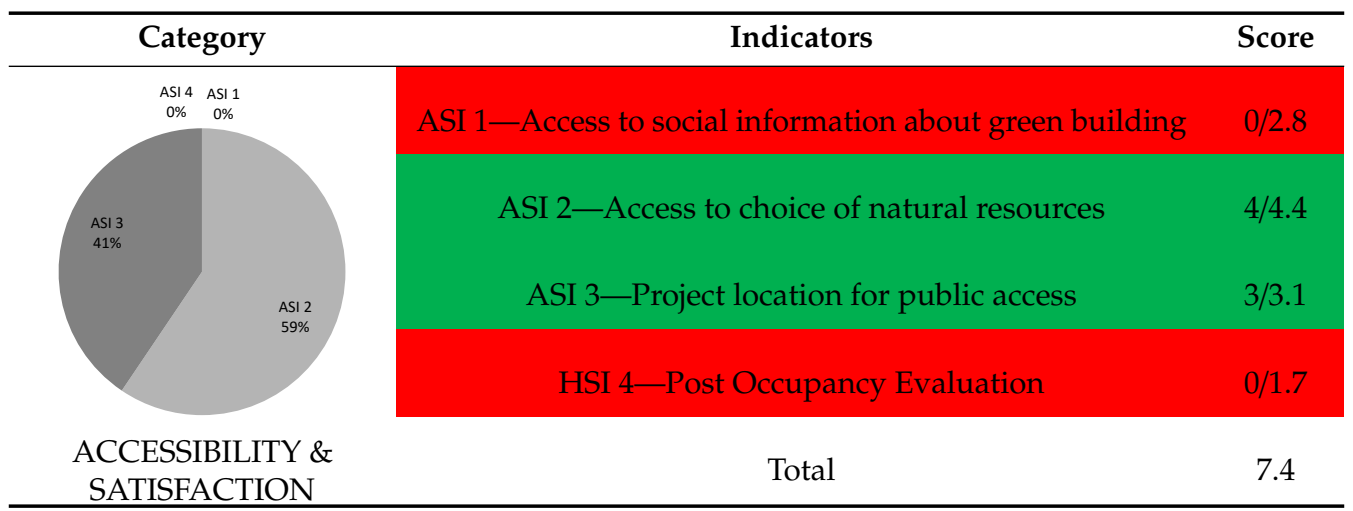

\subsection{Category 7: Cultural Value Indicator (CVI)}

The Cultural value category shows that the assessment of the indicators was of positive ratings with the design of spaces, indicating an above-average level of encouraging cultural aspect into designing of their spaces and the use of indigenous environmental management practices been highly encouraged in the community. Also, intercultural dialogue between individuals and groups of different cultural background exists which helps improve the environment (Table 14). 
Table 14. RAG rating of Cultural Value Indicator in Louroujina.

\begin{tabular}{lcc}
\hline Framework Category & Indicators & Score \\
\hline & CVI 1-Design of spaces & $1 / 1.4$ \\
& CVI 2-Indigenous environmental management practices & $1.7 / 1.7$ \\
& CVI 3-Intercultural dialogue & $0.6 / 0.6$ \\
CULTURAL VALUE & Total & 3.3 \\
\hline
\end{tabular}

\subsection{Category 8: Physical Resilience Indicator (PRI)}

The physical resilience category in Louroujina shows that all the indicator assessments were of low ratings, the compliance to earthquake resistance code having an unsatisfactory score, shows the low level of encouragement for the implementation of earthquake resistance code to building projects in the community, which in turn affect the management of hazards on projects. The mitigation in the use of the environmental resource is also low; this shows that there are not specified and regulated alternative environmental resources provided for the community to reduce harming the environment (see Table 15).

Table 15. RAG rating of Physical Resilience Indicator in Louroujina.

\begin{tabular}{lcc}
\hline Framework Category & Indicators & Score \\
\hline & PRI 2- Compliance to earthquake resistance code & $0 / 1.2$ \\
& PRI 3- Mitigation in the use of environmental resources & $0 / 0.7$ \\
PRI 4- Sustainable management of hazards & $0.2 / 0.9$ \\
\hline PRYI4 & Total & 0.2 \\
\hline
\end{tabular}

As an overview of the entire, Table 16 below is prepared to demonstrate the evaluation of Building in Louroujina, Table 16, present the total evaluation checklist of the building through the "SCGBAT" framework. The Building in Louroujina was placed within the Gold rating of the framework, which seen is Table 14 . The table shows a $77.9 \%$ in the final rating for all the indicators in louroujina's building. 
Table 16. "Social Criteria of Green Building Assessment Tool (SCGBAT)" Framework: Louroujina.

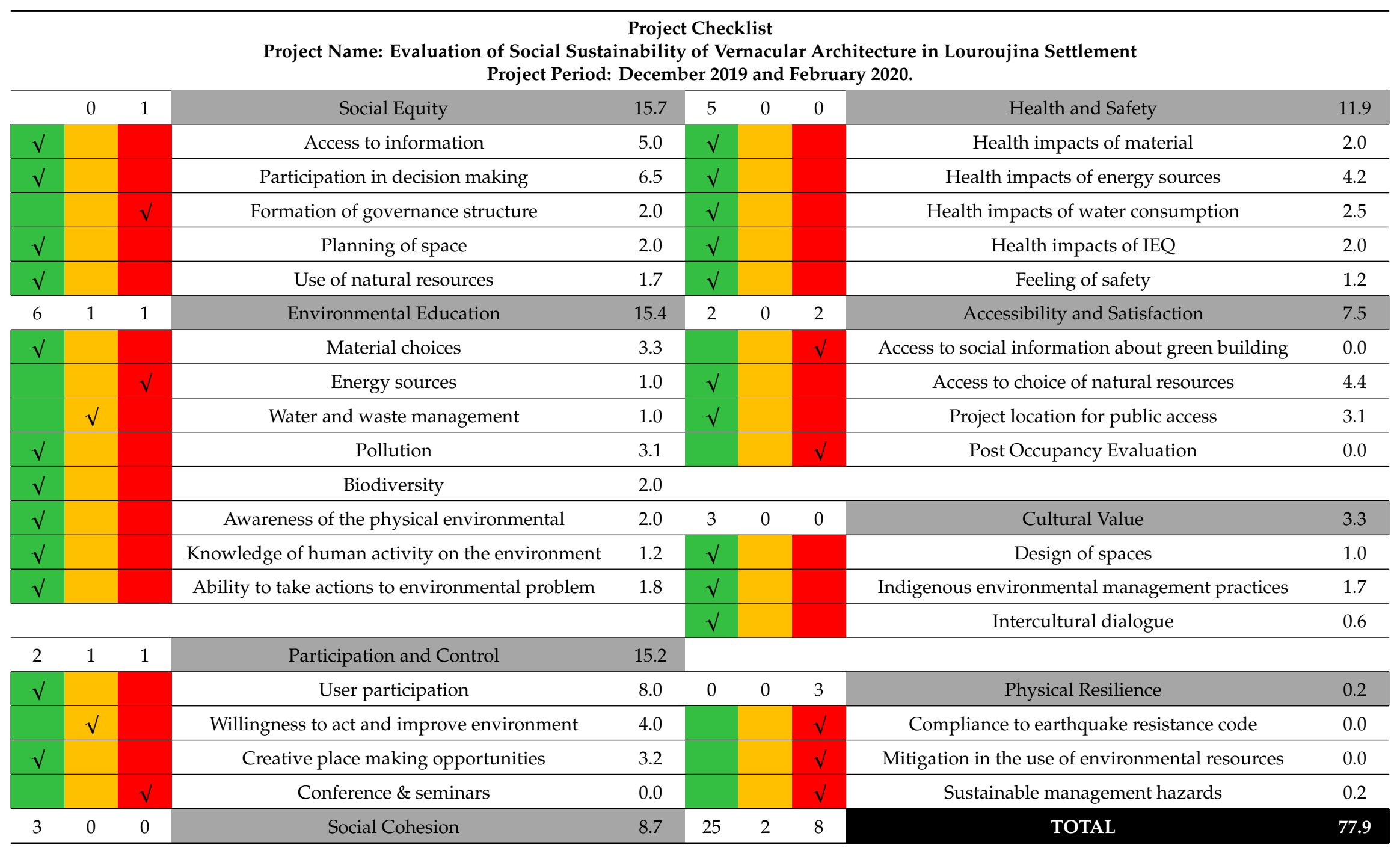


Table 16. Cont.

\begin{tabular}{|c|c|c|c|}
\hline \multicolumn{4}{|c|}{$\begin{array}{c}\text { Project Checklist } \\
\text { Project Name: Evaluation of Social Sustainability of Vernacular Architecture in Louroujina Settlement } \\
\text { Project Period: December } 2019 \text { and February } 2020 .\end{array}$} \\
\hline$\sqrt{ }$ & $\begin{array}{c}\text { Neighborhood involvement in design and planning } \\
\text { phases }\end{array}$ & 2.9 & \multirow{3}{*}{ Certified: $45-54 \%$, Silver: 55-64\%, Gold: $65-79 \%$, Platinum: $80-100 \%$} \\
\hline$\sqrt{ }$ & $\begin{array}{c}\text { Design of a place which increases social interaction } \\
\text { within the building }\end{array}$ & 2.9 & \\
\hline$\sqrt{ }$ & $\begin{array}{c}\text { Design of a place which increases social interaction } \\
\text { with common spaces (fluid spaces) in the } \\
\text { neighborhood }\end{array}$ & 2.9 & \\
\hline
\end{tabular}




\section{Discussion}

The results demonstrated that the investigated vernacular architecture lacked in; Physical Resilience Indicator (PRI), Environmental Education Indicator (EEI), Accessibility and Satisfaction Indicator (ASI) but satisfactorily better in the context of Health and Safety Indicator (HSI); Participation and Control Indicator (PCI); Social Equity Indicator (SEI); Social Cohesion Indicator (SCI); and Cultural Value Indicator (CVI).

The indicator of participation and control namely PCI 2-willingness to act and improve environment (4/8) and PCI 4-conference and seminar (0/0.9) demonstrated low responses from all the respondents. The low responses as regard the willingness to act is indicative of the fact that the young population of the village does not want to live in the vernacular architecture anymore and they prefer the contemporary alternatives they observe in the city. The Low response concerning the conference and seminar is simply self-evident since no such awareness raising conferences are organized in the village at any point. Also, two of the indicators of environmental education: EEI 4-Water and waste management (1/2.5) and EEI 2-Energy sources (1/3.2) ranked lowly from the responses. This is also indicative of the fact that in vernacular settlement, they rely on traditional indigenous knowledge of energy and energy sources, as such; formal knowledge of energy sources is not available [83]. In the same manner as the other two mentioned categories, the indicator of social equity: SEI 3-formation of governance structure (2/4.3) also ranked lowly in the responses. This is because; governance structure in Louroujina village is vested in a specific family. Furthermore, indicator: ASI 1- Access to social information about green building also ranked low because of the previously described factors about the preference for indigenous knowledge as against formal knowledge [84]. The indicator of physical resilience categories namely-PRI 2-compliance to earthquake resistance code (0/1.2), PRI 3-mitigation in the use of environmental resources (0/0.7) and PRI 4-sustainable management of hazards (0.2/0.9) demonstrated a low response from the experts. This is indicative of the fact that vernacular architecture was built based on a non-formal understanding of the concept of resilience and engineering compliance (Ibid.)

\section{Conclusions}

This paper assesses the social sustainability indicators in vernacular architecture through the application of a proposed set of 8 social sustainability categories and 37 indicators. The main proposed categories are health and safety; participation and control; education; equity, accessibility and satisfaction; social cohesion; cultural values; physical resilience [51,63]. The weighted score of each indicator was used to assess the social sustainability criteria of vernacular architecture in Louroujina village, Cyprus. One hundred and thirty five questionnaires were administered based on the 8 categories and the 37 indicators of social sustainability. One hundred and twenty one of the respondents were residents and occupants of the four residential typologies of vernacular architecture in Louroujina village while the other 14 respondents are professionals and experts working closely on projects in the village. These expert groups include the academia, the staff of the department of antiquity, staff of the municipality office and heritage site managers among others (see Table 5). The respondents were asked to assess the indicators in five-point Likert scale. As demonstrated by the analysis of results, the vernacular architecture in Louroujina village demonstrated a nearly satisfactory level of social sustainability from the respondents.

In this regard, this paper contributes to the advancement of knowledge concerning the assessment of social indicators in vernacular architecture which has witnessed less advancement in recent years. Also, this study has demonstrated the empirical application of the proposed conceptual SCGBAT assessment tool, especially, its compatibility, strengths and weaknesses in the context of assessing social values in vernacular landscapes. While several methods have been applied to assess the sustainability lessons of vernacular architecture over the years, green building assessment approach remains in a dearth. Against this background, by applying a green building assessment approach, this paper demonstrates that there are considerable lessons that can be drawn from vernacular architecture in 
the context of social sustainability. In this regard, the outcomes of this research can be used as an empirical basis for assessing the social sustainability of vernacular architecture which has long been ignored. However, in the course of the study, it was realized there are several other indicators of social sustainability of vernacular architecture that were not considered in the SGCBAT proposed categories and indicators. While the indicators proposed by the SCGBAT are important, some of the indicators are however not in tandem with the traditional philosophy of vernacular architecture in some cases. Thus, for future research, it is suggested that the categories and indicators be developed contextually using a vernacular settlement as a case study. The indicators and categories can be improved by using more in-depth vernacular architecture case study, creating different categories and adding more regionally specific indicators.

Author Contributions: Conceptualization, O.A.P.O. and J.O.A.; methodology, O.A.P.O. and J.O.A.; formal analysis, J.O.A.; investigation, O.A.P.O. and J.O.A.; resources, O.A.P.O. and J.O.A.; data O.A.P.O. and J.O.A.; writing-original draft preparation, O.A.P.O.; writing—review and editing, O.A.P.O.; visualization, O.A.P.O. and J.O.A. All authors have read and agreed to the published version of the manuscript.

Funding: This research received no external funding.

Acknowledgments: Authors want to express gratitude to the entire staff of Louroujina Municipality and the department of Architecture, Cyprus International University for the support throughout the research.

Conflicts of Interest: The authors declare no conflict of interest.

\section{References}

1. Vellinga, M. The noble vernacular. J. Arch. 2013, 18, 570-590. [CrossRef]

2. Praytino, B.; Winaktoe, W.W. Paradigm Shift towards Ecological (Vernacular) Settlement: Measuring the Dynamics within the Built-environment. In Proceedings of the ISVS 2, Jaskarta, Indonesia, 16-17 February 2002.

3. Dayaratne, R. Vernacular settlements and sustainable traditions in Sri Lanka. In Proceedings of the First Vernacular Settlement Conference at the University of Indonesia, Depok, Indonesia, 3-4 August 1999.

4. Dayaratne, R. Learning from tradition for an environmentally responsive architecture in Sri Lanka: A formal practice. Open House Int. 2000, 25, 5-15.

5. Shaffer, M. New Machine Vernacular: Remote Building Devises Digital/Cultural accommodation and technology's renewed humanitarian agenda. In Proceedings of the ISVS 5, Colombo, Sri Lanka, 30-31 July 2010.

6. Polèse, M.; Stren, R.E. The Social Sustainability of Cities: Diversity and the Management of Change; University of Toronto Press: Toronto, ON, Canada, 2000.

7. Becker, E.; Jahn, T. Sustainability and the Social Sciences; Zed Books: New York, NY, USA, 1999.

8. Chiu, R.L.H. Social Sustainability, Sustainable Development and Housing Development: The Experience of Hong Kong. In Housing and Social Change: East-West Perspectives; Forrest, R., Lee, J., Eds.; Routledge: Florence, SC, USA, 2003; pp. 221-239.

9. Enyedi, G. Social sustainability of large cities. Ekistics 2002, 69, 42-144.

10. Levi-Strauss, C. The Way of the Masks; University of Washington Press: Seattle, WA, USA, 1982.

11. Correia, M.; Dipasquale, L.; Mecca, S. (Eds.) Versus: Heritage for Tomorrow; Firenze University Press: Firenze, Italy, 2014.

12. Heath, K. Vernacular Architecture and Regional Design; Routledge: Abingdon, UK, 2009.

13. AA.VV. Vernacular Architecture: ICOMOS International Committee on Vernacular Architecture. International Scientific Committee. In Proceedings of the 10th General Assembly, Battaramulla, Sri Lanka, 30 July4 August 1993.

14. Buyukmihci, G.; Bilsel, G.; Hisarligil, H.; Polat, E. Sustainable Traditional Environment Commencing a New Strategy to Re- insure the Cultural Continuity in Gesi and Surrounding Small Settlements. In Traditional Environments in a New Millenium; Turgut, H., Kellett, P., Eds.; IAPS-CSBE Network Book Series 4; Istanbul Technical University: Instanbul, Turkey, 2002; pp. 229-232.

15. Numan, I.; Dincyurek, O. Learning from Cyprus and its traditional Mesaorian adobe architecture. In Proceedings of the ISVS 2, Depok, Indonesia, 16-17 February 2012; pp. 219-226.

16. Burr, P. Comparative analysis of comfort levels in five selected South Florida residences. In Proceedings of the First International PLEA Conference, Bermuda, UK, 13-15 September 1982; pp. 3.12-3.18. 
17. Sahlins, M. What is anthropological enlightenment? Some lessons of the twentieth century. Annu. Rev. Anthropol. 1999, 28, i-xxiii. [CrossRef]

18. Stasinopoulos, T.N. The four elements of Santorini architecture: Lessons in vernacular sustainability. In Proceedings of the PLEA2006-The 23rd Conference on Passive and Low Energy Architecture, Geneva, Switzerland, 6-8 September 2006; Volume 2, pp. 73-78.

19. Antarikananda, P.; Douvlou, E.; McCartney, K. Lessons from traditional architecture: Design for a climatic responsive contemporary house in Thailand. In Proceedings of the PLEA2006 23rd Conference on Passive and Low Energy Architecture, Geneva, Switzerland, 6-8 September 2006; pp. 6-8.

20. Eyüce, A. Learning from the Vernacular: Sustainable Planning and Design. Open House Int. 2007, 32, 9-22.

21. Roaf, S. The traditional technology trap (2): More lessons from the windcatchers of Yazd. In Proceedings of the PLEA 25th Conference on Passive and Low Energy Architecture, Dublin, Ireland, 22-24 October 2008; p. 739.

22. Kazimee, B.A. Learning from vernacular architecture: Sustainability and cultural conformity. WIT Trans. Ecol. Environ. 2008, 113, 3-13.

23. Anna-Maria, V. Evaluation of a sustainable Greek vernacular settlement and its landscape: Architectural typology and building physics. Build. Environ. 2009, 44, 1095-1106. [CrossRef]

24. Ellen, R.F.; Parker, P.; Bicker, A. Indigenous Environmental Knowledge and Its Transformations: Critical Anthropological Perspectives; Harwood: Amsterdam, The Netherlands, 2000.

25. Fernandes, J.; Mateus, R.; Braganca, L.; Da Silva, J.J.C. Portuguese Vernacular Architecture: The contribution of vernacular materials and design approaches for sustainable construction. Archit. Sci. Rev. 2015, 58, 323-336. [CrossRef]

26. Hosseini, E.; Mursib, G.; Nafida, R.; Shahedi, B. Malay Vernacular Architecture: Mirror of the Past. Lessons for the Future. In Proceedings of the 8th Seatuc Symposium Universiti Teknologi Malaysiaat, Johor, Malaysia, 4-5 March 2014; pp. 1-6.

27. Olukoya, A.O.; Kurt, S. Environmental impacts of adobe as a building material: The north Cyprus traditional building case. Case Stud. Constr. Mater. 2016, 4, 32-41. [CrossRef]

28. Olukoya, A.O. Built heritage as catalysts of environmental sustainability: A pragmatic paradigm for Anthropocene. In Vernacular and Earthen Architecture: Conservation and Sustainability; CRC Press: Boca Raton, FL, USA, 2017; pp. 657-662.

29. Tawayha, F.A.; Braganca, L.; Mateus, R. Contribution of the vernacular architecture to the sustainability: A comparative study between the contemporary areas and the old quarter of a Mediterranean city. Sustainability 2019, 11, 896. [CrossRef]

30. Foruzanmehr, A.; Vellinga, M. Vernacular architecture: Questions of comfort and practicability. Build. Res. Inf. 2011, 39, 274-285. [CrossRef]

31. Foruzanmehr, A. Resident's perception of earthen dwellings in Iran. Int. J. Urban Sustain. Dev. 2012, 5, 179-199. [CrossRef]

32. Foruzanmehr, A. Summer-time thermal comfort in vernacular earth dwellings in Yazd, Iran. Int. J. Sustain. Des. 2012, 2, 46-63. [CrossRef]

33. Foruzanmehr, A. The wind-catcher: Users' perception of a vernacular passive cooling system. Archit. Sci. Rev. 2012, 55, 250-258. [CrossRef]

34. Foruzanmehr, A. Thermal comfort and practicality: Separate winter and summer rooms in Iranian traditional houses. Archit. Sci. Rev. 2014, 59, 1-11. [CrossRef]

35. Foruzanmehr, A. Basements of vernacular earth dwellings in Iran: Prominent passive cooling systems or only storage spaces? Int. J. Urban Sustain. Dev. 2015, 7, 232-244. [CrossRef]

36. Foruzanmehr, A. People's perception of loggia: A vernacular passive cooling system in Iranian architecture. Int. J. Sustain. Cities Soc. 2015, 19, 61-67. [CrossRef]

37. Yadav, M. Embodied Energy in Vernacular Houses. Case study of Goari Settlement, Mumbai, India. In Proceedings of the ISVS 5 Conference, Moratuwa, Sri Lanka, 30-31 July 2010; pp. 72-84.

38. Fathy, H. Architecture for the Poor: An Experiment in Rural Egypt; University of Chicago Press: Chicago, IL, USA, 1976.

39. Rasavi, M. Harmonization between Architecture Nature in Howraman. ISVS 2008, 4, 543-550.

40. Tokman, L.Y.; Yamacli, R.; Yanilmaz, B. The Context of Sustainability Space; (IAPS-CSBE Network book 4); Istanbul Technical University: Istanbul, Turkey, 2002; pp. 87-89. 
41. Tucker, S.; Gamage, A. Some design aspects of sustainable post-disaster housing. Int. J. Disaster Resil. Built-Environ. 2014, 5, 163-181. [CrossRef]

42. Frey, P. Learning from Vernacular: Towards a New Vernacular Architecture; Actes Sud: Arles, France, 2010.

43. Dayaratne, R. Toward sustainable development: Lessons from vernacular settlements of Sri Lanka. Front. Archit. Res. 2018, 7, 334-346. [CrossRef]

44. Rapoport, A. House Form and Culture; Prentice Hall: Englewood Cliffs, NJ, USA, 1969.

45. Alexander, C. A Pattern Language: Towns, Buildings, Construction; Oxford University Press: New York, NY, USA, 1977.

46. Oliver, P. Shelter for All: Continuity and change in the world housing. In Proceedings of the ISVS 5 Conference, Moratuwa, Sri Lanka, 30-31 July 2010; pp. 1-5.

47. He, B.-J. Towards the next generation of green building for urban heat island mitigation: Zero UHI impact building. Sustain. Cities Soc. 2019, 50, 101647. [CrossRef]

48. Atanda, J.O.; Olukoya, O.A. Green building standards: Opportunities for Nigeria. J. Clean. Prod. 2019, 227, 66-377. [CrossRef]

49. Nguyen, B.K.; Altan, H. Comparative review of five sustainable rating systems. In 2011 international conference on green buildings and sustainable cities. Procedia Eng. 2011, 21, 376-386. [CrossRef]

50. Cole, R.J. Building environmental assessment methods: Redefining intentions. In Proceedings of the 2005 World Sustainable Building Conference, Tokyo, Japan, 27-29 September 2005; pp. 1934-1939.

51. Atanda, J.O.; Öztürk, A. Social criteria of sustainable development in relation to green building assessment tools. Environ. Dev. Sustain. 2018, 22, 61-87. [CrossRef]

52. Holmberg, J. Making Development Sustainable: Redefining Institutions Policy and Economics; Island Press: Washington, DC, USA, 1992.

53. Reed, D. Review brief-structural adjustment, the environment, and sustainable development. Long Range Plan. 1997, 30, 143-144. [CrossRef]

54. Elkington, J. Cannibals with Forks—Triple Bottom Line of 21st Century Business; New Society Publisher: Stoney Creek, CT, USA, 1997.

55. OECD. Sustainable Development: Critical Issues; OECD: Paris, France, 2001.

56. Jenkins, V. Commission of the European Communities: A Sustainable Europe for a Better World: A European Union Strategy for Sustainable Development. Communication from the Commission (Commission's proposal to the Gothenburg European Council). COM(264) Final. 2001, pp. 240-261. Available online: https://ec.europa. eu/regional_policy/archive/innovation/pdf/library/strategy_sustdev_en.pdf (accessed on 1 September 2020).

57. Harris, J.M.; Timothy, A.W.; Kevin, P.G.; Neva, R.G. (Eds.) A Survey of Sustainable Development: Social and Economic Dimensions; Island Press: Washington, DC, USA, 2001; Volume 6.

58. Savitz, A.; Weber, K. The Triple Bottom Line: How Today's Best-Run Organizations Are Achieving Economic, Social and Environmental Success-And How You Can Too; Jossey Bass: San Francisco, CA, USA, 2006.

59. Epstein, M. Making Sustainability Work: Best Practices in Managing and Measuring Corporate Social, Environmental, and Economic Impacts; Greenleaf: San Francisco, CA, USA, 2008.

60. Komeily, A.; Srinivasan, R.S. A need for balanced approach to neighborhood sustainability assessments: A critical review and analysis. Sustain. Cities Soc. 2015, 18, 32-43. [CrossRef]

61. Sachs, I. Social Sustainability and Whole and Whole Development: Exploring the Dimensions of Sustainable Development; Zed Book: London, UK, 1999.

62. Sharifi, A.; Murayama, A. A critical review of seven selected neighborhood sustainability assessment tools. Environ. Impact Assess. Rev. 2013, 38, 73-87. [CrossRef]

63. Atanda, J.O. Developing a social sustainability assessment framework. Sustain. Cities Soc. 2019, 44, $237-252$. [CrossRef]

64. Dawson, C. Practical Research Methods: A User-Friendly Guide to Mastering Research Techniques and Projects; How to Books Ltd.: Oxford, UK, 2002.

65. Olukoya, O.P. Energy Efficiency in Traditional Buildings: The Louroujina; North Cyprus Case: Nicosia, Cyprus, 2015.

66. Norberg-Schulz, C. Genius Loci: Towards a Phenomenology of Architecture; Rizzoli Publisher: New York, NY, USA, 1980.

67. Belluschi, P. The Meaning of Regionalism in Architecture; Architectural Record: New York, NY, USA, 1955. 
68. Finizola, F.; Coutinho, S.; Cavalcanti, V. Vernacular design: A discussion on its concept. In Proceedings of the Design Frontiers: Territories, Concepts, Technologies, 8th Conference of the International Committee for Design History Design Studies-ICDHS, Sao Paulo, Brazil, 3-6 September 2012; pp. 557-561.

69. Kurt, S.; Bay, I.; Mesda, M.; Shagbaor, T.; Isik, B. Repairing and Maintaining Damaged Buildings in Louroujina Village/Cyprus: A Case Study for Old Khan. In Proceedings of the Kerpic '13. New Generation Earthen Architecture: Learning from Heritage, Istanbul, Turkey, 11-15 September 2013; Yücel, G.F., Ed.; pp. 475-485.

70. Kiessel, M.; Kurt, S.; Mesda, Y. The Abandoned Khan of Louroujina, Cyprus: A Case Study of a Vanishing Building Type. Adalya 2016, 19, 323-347.

71. Goodwin, J.C. An Historical Toponymy of Cyprus, 4th ed.; Private Publication: Nicosia, Cyprus, 1984.

72. TÜBITAK Project 112M417. Kıbrıs- Akıncılar Köyünün Korunması, Rehabilitasyonu ve Yeniden Canlandırılması Kapsamında Yerel bir Kalkınma Stratejisi Geliştirilmesi Preojesi 1. Gelişim Raporu, Lulu: USA. 2013.

73. Yin, R.K.; Yin, R.K. Case Study Research: Design and Methods (Applied Social Research Methods); Sage: London, UK; Singapore, 2009.

74. Likert, R. A technique for the measurement of attitudes. In ARCH Psychological; Columbia University Press: New York, NY, USA, 1932; p. 140.

75. Hartley, S.L.; MacLean, W.E., Jr. A review of the reliability and validity of Likert-type scales for people with intellectual disability. J. Intellect. Disabil. Res. 2006, 50, 813-827. [CrossRef]

76. Sivo, S.A.; Saunders, C.; Chang, Q.; Jiang, J.J. How low should you go? Low response rates and the validity of inference in IS questionnaire research. J. Assoc. Inf. Syst. 2006, 7, 17. [CrossRef]

77. Miller, G. The development of indicators for sustainable tourism: Results of a Delphi survey of tourism researchers. Tourism Manag. 2001, 22, 351-362. [CrossRef]

78. Hugé, J.; Le Trinh, H.; Hai, P.H.; Kuilman, J.; Hens, L. Sustainability indicators for clean development mechanism projects in Vietnam. Environ. Dev. Sustain. 2010, 12, 561-571. [CrossRef]

79. Skulmoski, G.J.; Hartman, F.T.; Krahn, J. The Delphi method for graduate research. J. Inf. Technol. Educ. Res. 2007, 6, 1-21. [CrossRef]

80. Delbecq, A.L.; Van de Ven, A.H.; Gustafson, D.H. Group Techniques for Program Planning: A Guide to Nominal Group and Delphi Processes; Scott Foresman: Glenview, IL, USA, 1975.

81. Taylor-Powell, E. Collecting group data: Delphi technique. In Program Development and Evaluation; University of Wisconsin-Extension: Madison, WI, USA, 2002; Available online: http://www.uwex.edu/ces/pdande/ resources/pdf/Tipsheet4.pdf (accessed on 1 September 2020).

82. Coutinho, S.S.; Freitas, M.A.; Pereira, M.J.B.; Veiga, T.B.; Ferreira, M.; Mishima, S. MUse of Delphi technique in research in the primary health care: Integrative. Rev. Baiana Saúde Pública 2013, 37, 582-596.

83. Brown, R.; Maudlin, D. Concepts of vernacular architecture. In The SAGE Handbook of Architecture Theory; Sage: London, UK, 2012; pp. 340-368.

84. Özkan, S.; Turan, M.; Üstünkök, O. Institutionalised Architecture, Vernacular Architecture and Vernacularism in Historical Perspective. METU J. Fac. Archit. 1979, 5, 127-156.

(C) 2020 by the authors. Licensee MDPI, Basel, Switzerland. This article is an open access article distributed under the terms and conditions of the Creative Commons Attribution (CC BY) license (http://creativecommons.org/licenses/by/4.0/). 